4. The ratio of potassium to sodium decreased significantly with advancing age in kidney and heart tissue.

5. Nine tissues were analysed from a further five LK and five HK aged ewes. The skeletal muscle, liver, spleen and kidney (expressed on a fat- and blood-free basis) of the aged HK ewes tended to have higher concentrations of potassium $(1.5,2.2,3.6$ and $1.9 \%$ respectively) and lower concentrations of sodium $(10 \cdot 7,12 \cdot 3,9 \cdot 2$ and $4.8 \%$ respectively) than those of the aged LK ewes.

6. Rumen epithelium from LK sheep had a significantly lower potassium concentration $(19.5 \%)$ than that from $\mathrm{HK}$ animals.

7. The fat content of the skeletal muscle of aged LK sheep was significantly higher (17 g. of fat $/ \mathrm{kg}$. wet wt. or about $48 \%$ ) than that of aged HK' sheep but this difference was not found in a group of lambs of the same breed.

We wish to express our appreciation to Dr A. T. Phillipson, Head of the Physiology Department, for his advice and very helpful discussions. We would also like to thank G. C. Anderson, M. Duncan and E. D. Brown for their valuable technical assistance.

\section{REFERENCES}

Abderhalden, E. (1898). Hoppe-Seyl. Z. 25, 65.

Bing, F. C. \& Baker, R. W. (1931). J. biol. Chem. 92, 589.

Davies, F., Davies, R. E., Francis, E. T. B. \& Whittam, R. (1952). J. Physiol. 118, 276.
Denton, D. A., Wynn, V., McDonald, I. R. \& Simon, S. (1951). Acta med. scand. 140, Suppl. 261.

Eichelberger, L. \& Bibler, W. G. (1940). J. biol. Chem. 132, 645.

Evans, J. V. (1954). Nature, Lond., 174, 931.

Evans, J. V. (1957a). J. Physiol. 136, 41.

Evans, J. V. (1957b). Nature, Lond., 180, 756.

Evans, J. V., Harris, H. \& Warren, F. L. (1958a). Proc. Roy. Soc. B, 148, 249.

Evans, J. V., Harris, H. \& Warren, F. L. (1958b). Nature, Lond., 182, 320.

Evans, J. V. \& King, J. W. B. (1955). Nature, Lond., 176, 171.

Evans, J. V., King, J. W. B., Cohen, B. L., Harris, H. \& Warren, F. L. (1956). Nature, Lond., 178, 849.

Evans, J. V. \& Mounib, M. S. (1957). J. agric. Sci. 48, 433.

Fenn, W. O. (1939). J. biol. Chem. 128, 297.

Fowler, R., jun. \& Upfill, J. (1955). Aust. J. exp. Biol. med. Sci. 33, 39.

Harris, H., McDonald, I. R. \& Williams, W. (1952). Aust. J. exp. Biol. med. Sci. 30, 33.

Harrison, H. E. \& Darrow; D. C. (1938). J. clin. Invest. 17, 77.

Hastings, A. B. \& Eichelberger, L. (1937). J. biol. Chem. 117, 73.

Kerr, S. E. (1937). J. biol. Chem. 117, 227.

Laramore, D. C. \& Grollman, A. (1950). Amer. J. Physiol. $161,278$.

Lowry, O. H., Hastings, A. B., McCay, C. M. \& Brown, A. N. (1946). J. Geront. 1, 345.

Mounib, M. S. \& Evans, J. V. (1957). Analyst, 82, 522.

Snedecor, G. W. (1955). Statistical Methods, 4th ed. Ames, Iowa: The Iowa State College Press.

Widdas, W. F. (1954). J. Physiol. 125, $18 P$.

Yannet, H. \& Darrow, D. C. (1938). J. clin. Invest. 17, 87.

Biochem. J. (1960) 75, 82

\title{
Comparative Biochemistry of Urea Synthesis
}

\section{ACTIVITIES OF UREA-CYCLE ENZYMES IN VARIOUS HIGHER AND LOWER VERTEBRATES*}

\author{
By G. W. BROWN, Jun. ANd P. P. COHEN \\ Department of Physiological Chemistry, University of Wisconsin School of Medicine, \\ Madison, Wisconsin, U.S.A.
}

(Received 9 July 1959)

In the first paper of this series we reported on a systematic scheme of analysis for determining quantitatively the activity of urea-cycle enzymes in liver extracts of ureotelic animals (Brown \& Cohen, 1959a). Application of this method to livers of Rana catesbeiana tadpoles revealed the induction of the cycle at the onset of metamorphosis (Brown \& Cohen, 1958, 1959b). It was also

\footnotetext{
* Part 2: Brown \& Cohen (1959b).
}

found that the activity of the urea-cycle enzymes could account for the rate of urea synthesis by anuran liver as judged by the rate of urea excretion by intact, metamorphosing tadpoles. This offered final and convincing evidence that the urea cycle as formulated in Fig. 1 (see Brown \& Cohen, 1958; Cohen \& Brown, 1959; Ratner, 1954, 1955) represents the sequence of reactions for the biosynthesis of urea by a ureotelic organism. Moreover, the favourable free-energy changes associated with the 
individual steps of the cycle demonstrate the thermodynamic feasibility of these reactions (Cohen \& Brown, 1959).

The acquisition by tadpoles of the biochemical system for the synthesis of urea is thought to mimic in some degree the evolutionary course of nitrogen-excretion mechanisms (Brown \& Cohen, $1959 b$ ). The present paper is devoted to a further study of the evolutionary significance of the urea cycle, and an attempt is made to locate sites of enzymic alterations in the vertebrate evolutionary tree.

\section{METHODS AND MATERIALS}

The animals used in the present study were from a variety of commercial and private sources. Fresh livers were used. The preparation of liver extracts by the use of the detergent cetyltrimethylammonium bromide (Technical Grade, Eastman Kodak Co.) and the procedures for the enzymic assays have been described in detail previously (Brown \& Cohen, $1959 a$ ). With shark liver, the usual assay procedures were modified because of the large amount of urea present in whole extracts of liver. (The liver of one shark contained approx. $1 \%$ of urea.) Urea yields colour with the diacetyl monoxime reagent used for determining citrulline, the final product in the carbamyl phosphate synthetase and ornithine-transcarbamylase assays. The modification consisted of the addition of urease to the incubation medium to remove the interfering urea. A shark-liver pellet was prepared by homogenizing fresh liver in the cold with 10 vol. of iso-osmotic $\mathrm{KCl}$, centrifuging at $4000 \mathrm{~g}$ for $30 \mathrm{~min}$. (after an initial centrifuging at $600 \mathrm{~g}$ to remove nuclei and unbroken cells), washing the pellet twice with iso-osmotic $\mathrm{KCl}$ and extracting the pellet with water. Assays were performed on this water extract. Homogenates of lizard and snake liver for arginase assays were prepared in doubledistilled water. Cetyltrimethylammonium bromide ex-

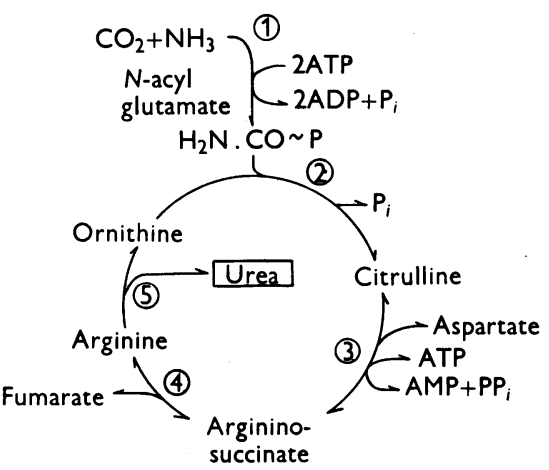

(1) Carbamyl phosphate synthetase

(2) Ornithine transcarbamylase

(3) Condensing enzyme

(4) Cleavage enzyme

Arginine synthetase

(5) Arginase

Fig. 1. Krebs \& Henseleit (1932) urea cycle as modified and completed by later enzymic studies. ATP, ADP, AMP, Adenosine tri-, di- and mono-phosphate respectively. tracts of such livers also exhibited arginase activity. Urease was Sigma type V (Sigma Chemical Co., St Louis, Mo.).

All assays were performed at $38^{\circ}$. One unit of enzyme equals $1 \mu$ mole of product formed/hr. The value, units/g., is based on wet weight of tissue.

The amount of protein (enzyme) employed in the carbamyl phosphate synthetase reaction must be controlled carefully to achieve maximum rates under assay conditions. The course of the reaction for carbamyl phosphate synthetase of an Amphiuma liver as a function of protein concentration is depicted in Fig. $2 \mathrm{~A}$. The rate falls off slightly as the protein concentration is increased. A plot of units/ $\mathrm{ml}$. of extract against ml. of extract, as shown in Fig. $2 B$, affords a linear extrapolation to the value on the ordinate axis of units of enzyme $/ \mathrm{ml}$. of extract for infinitesimally small protein concentrations. Linearity of carbamyl phosphate synthetase activity with increasing protein concentration can be obtained only when the reaction has proceeded to a small extent, such as is obtainable at low protein (enzyme) concentrations. Whenever possible it is advisable to compare an extrapolated value as indicated with the value obtained in routine assays. Such a procedure permits selection of an enzyme concentration low enough to afford a linear rate during the assay interval. Only then can valid comparisons be made among enzymes prepared from the livers of different species.

\section{RESULTS AND DISCUSSION}

The activities of urea-cycle enzymes in the livers of various vertebrates are tabulated in Table 1 . The data were obtained during the last 2 years and values reported for the various enzymic activities for a given species are not necessarily simultaneous assays for the several enzymes from given specimens of liver. For purposes of comparison with a common laboratory animal, we have included data of simultaneous assays for all the enzymes (except the cleavage enzyme) from five rat livers (Holtzman albino strain) performed in conjunction with studies on regenerating liver (Kim, 1959).

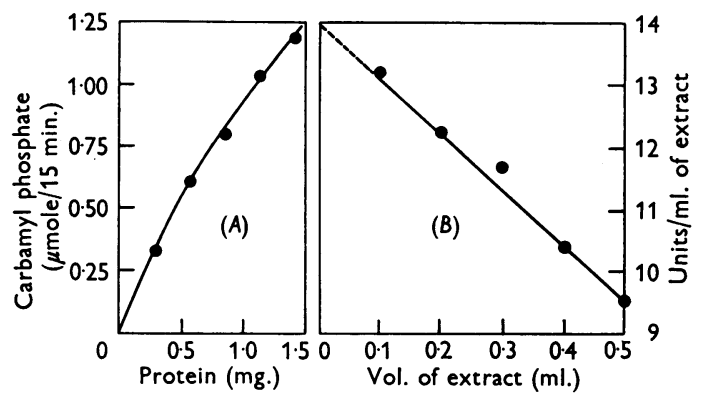

Fig. 2. Carbamyl phosphate synthetase of Amphiuma means. $A$, Amount ( $\mu$ moles) of carbamyl phosphate and protein concentration. $B$, Activity of enzyme (units $/ \mathrm{ml}$. of extract) and volume of extract; the straight-line plot extrapolates to 14 units/ml., corresponding to 252 units/ g. of liver wet wt. 
要

․ㅡ

密密

咅

$1=$

.

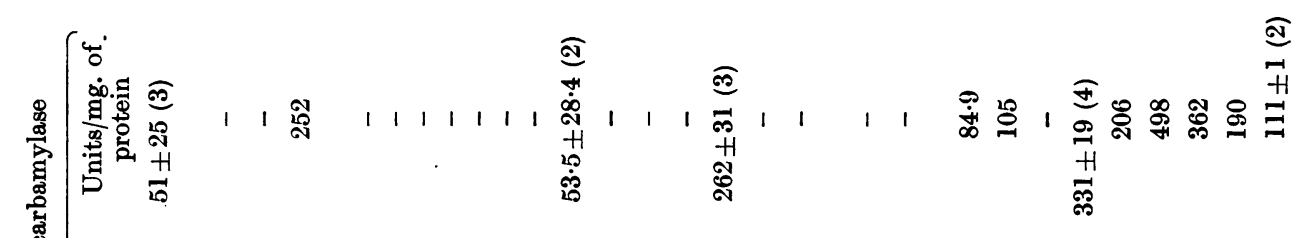

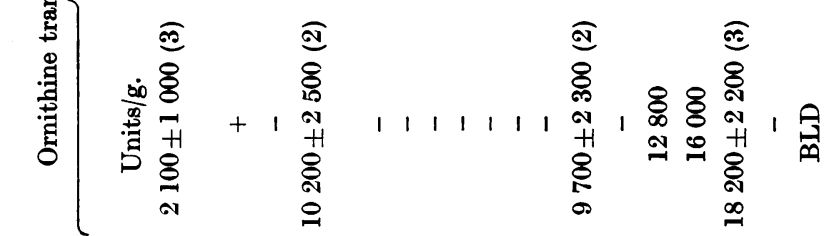

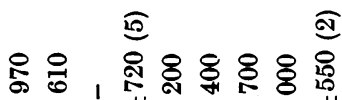

a

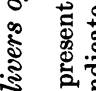

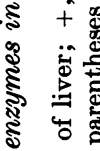

ङ

究

\$

के

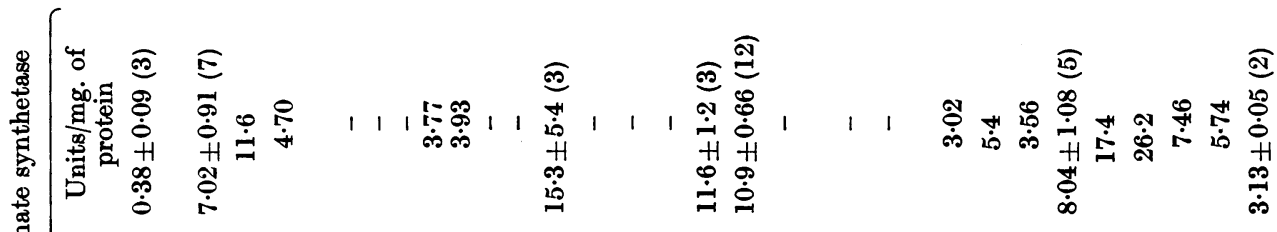

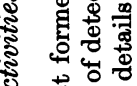

要

离

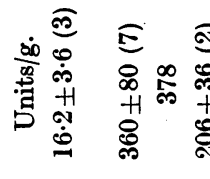

ติ

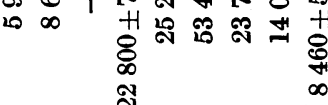

- 0 点

क पि

娄

कi

क्ष

छ용

蕗免

ส

家

承

总芯

需

迸离
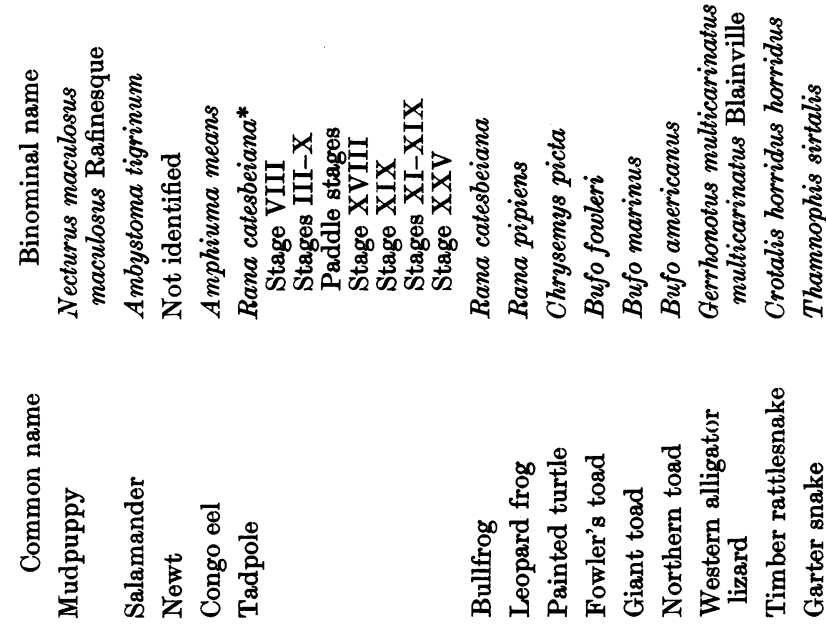


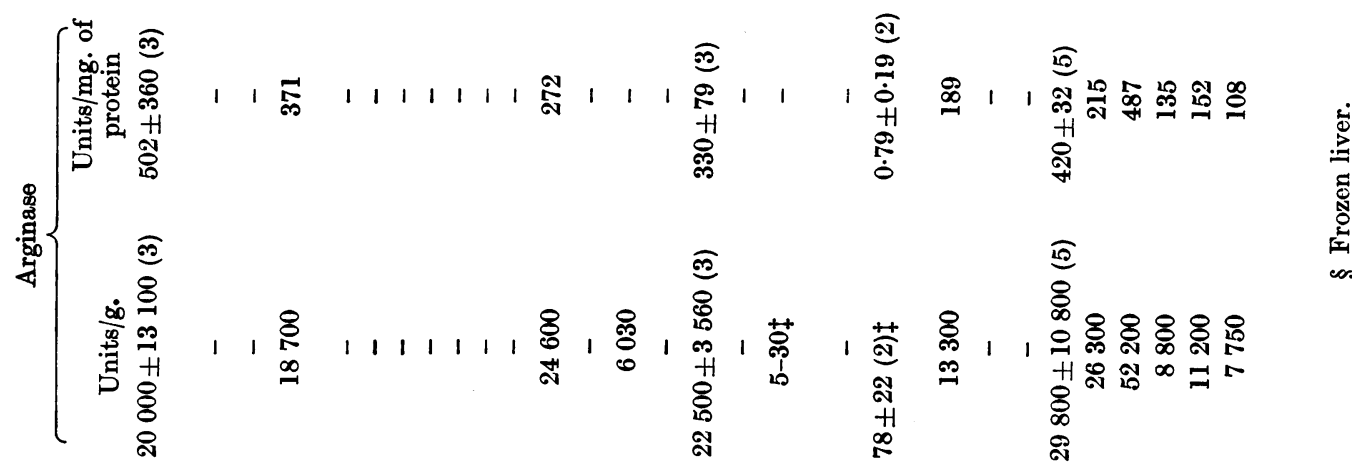

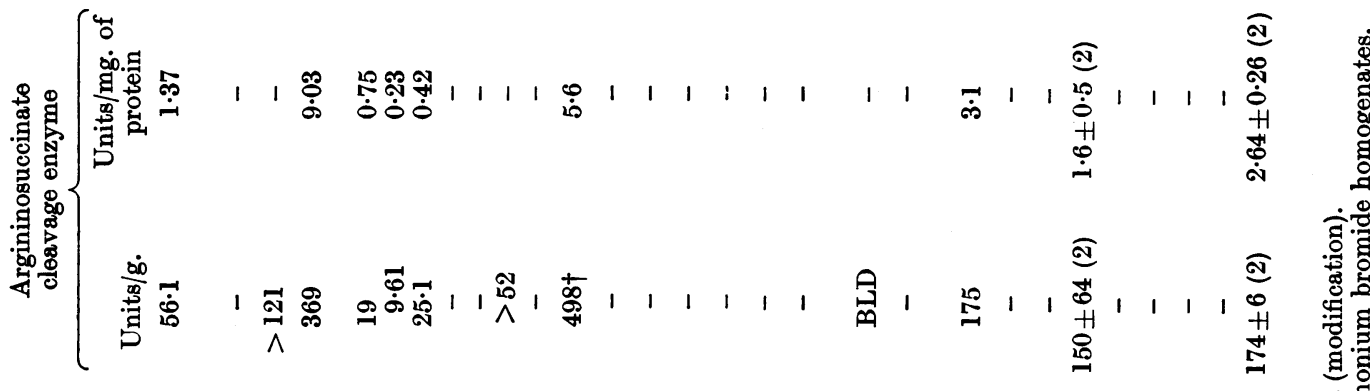

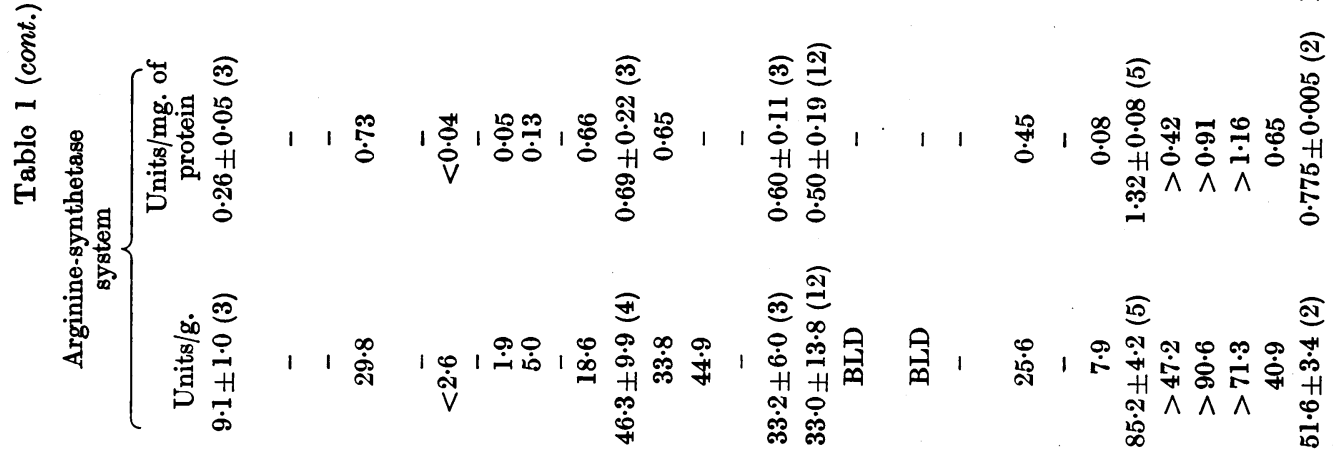

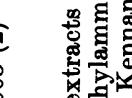

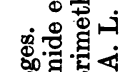

要遂窟占

으을

응 용

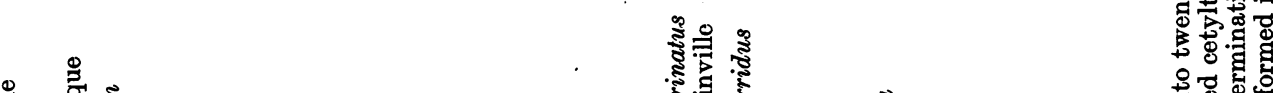

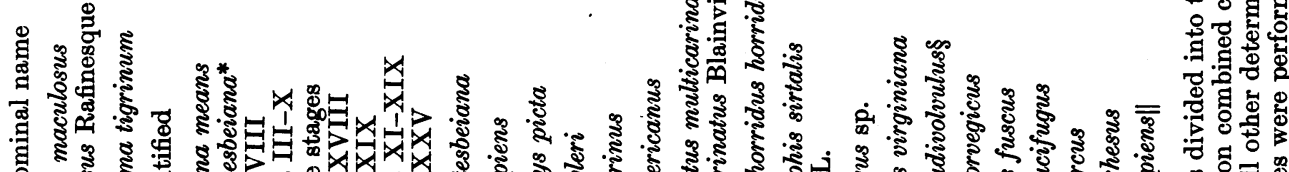

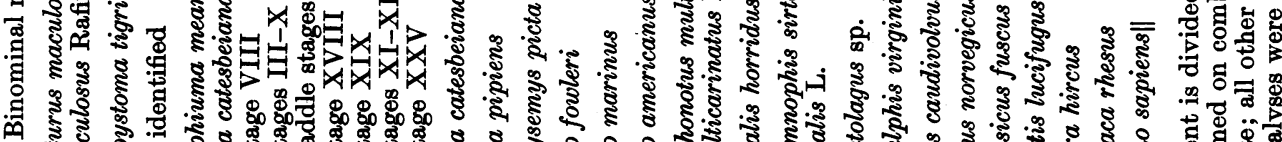

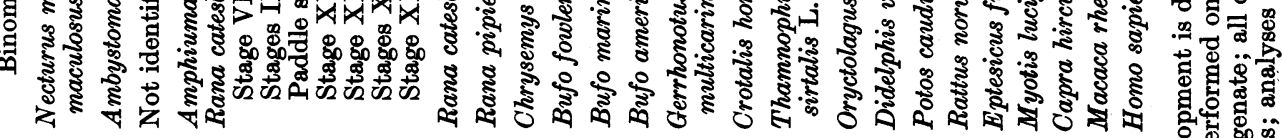

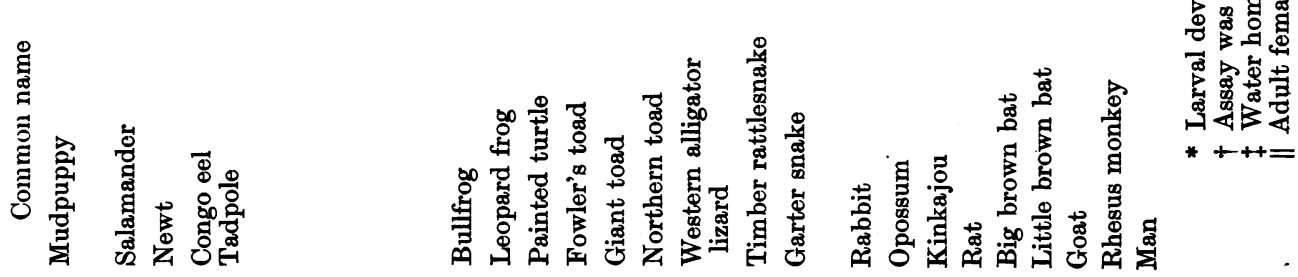


The results of a typical experiment for one of the assays are given for illustrative purposes. When Necturus liver was assayed for ornithine transcarbamylase, $2 \cdot 10 \mu$ moles of citrulline were produced in $30 \mathrm{~min}$. at $38^{\circ}$ with extract containing $84 \mu \mathrm{g}$. of protein; the amounts of citrulline (in $\mu$ mole) produced under the following conditions were: boiled enzyme, 0.35 ; no extract, $0 \cdot 28$; no ornithine, 0.22 ; no carbamyl phosphate, 0.04 (slight residual activity is attributed to nonenzymic transcarbamylation). The production of citrulline was linear with time over a $40 \mathrm{~min}$. period.

Urea-cycle enzymes have been observed in all species of the Anura, Urodela and Mammalia examined to date. In addition, the painted turtle (terrapin), Chrysemys picta, a representative species of the chelonian reptiles, also possessed these enzymes. Carbamyl phosphate synthetase, the arginine-synthetase system and the argininosuccinate-cleavage enzyme could not be demonstrated in the liver of the timber rattle-snake, Crotalus horridus horridus, and studies with the livers of pigeon and sparrow indicated that the enzymes of the cycle in these were also below the limit of detection by the assay procedures (cf. Grisolia \& Cohen, 1953). These findings are consistent with previous studies on the distribution of ammono-, ureo- and urico-telism among various groups of animals (Needham, 1931; Prosser, 1950). Thus birds and reptiles, except certain turtles (Moyle, 1949), are uricotelic, amphibians and mammals are ureotelic and the bony fish, the Teleostei, are ammonotelic. It is known that carbamyl phosphate-synthetase and ornithinetranscarbamylase activities are below the present limits of detection in the livers of the last-named. W. D. Brown and G. H. Burnett, in the authors' Laboratory (unpublished work), could demonstrate the presence of neither carbamyl phosphate synthetase nor ornithine transcarbamylase in acetonedried powders of the livers of Holostei, e.g. the gar pike (Lepidosteus osseus oxyurus) and the bowfin (Amia calva), nor in the Teleostei, e.g. the perch (Perca flavescens), the carp (Cyprinus carpio) and the brown trout (Salmo trutta fario).

All of the urea-cycle enzymes could be demonstrated in the livers of rabbits, monkeys, humans, bats, the South American kinkajou and the opossum. The activities of the enzymes of the bats, Eptesicus fuscus and Myotis lucifugus, were especially high. The liver of the former had a value for carbamyl phosphate synthetase of 2130 units/g. Activity could be demonstrated in bat liver that had been immediately frozen and stored at $-18^{\circ}$ for 1 week.

Elasmobranchs contain a high concentration of urea in the blood which serves in an osmotic sense to maintain near tonicity with sea water (see Baldwin, 1949; Prosser, 1950). Baldwin (1958) has found that all enzymes of the cycle, with the exception of carbamyl phosphate synthetase, are present in acetone-dried powders of the livers of a variety of Pacific cartilaginous fishes. Some studies performed in 1956 (Brown, 1959; cf. Cohen \& Brown, 1959) also provided evidence for the occurrence of ornithine transcarbamylase in acetone-dried powders of shark liver, but no activity could be demonstrated for carbamyl phosphate synthetase.

Carbamyl phosphate-synthetase activity could not be demonstrated in several samples of liver from the shark, Squalis sucklii Bernard. In the assays, some spurious colour developed during the determination for citrulline; the nature of this chromogenic substance is unknown at present. If carbamyl phosphate is indeed formed by shark liver, the enzyme could not be detected by the non-isotopic procedure used here for demonstrating this enzyme activity in the liver of other ureotelic vertebrates. A final answer must await assays by the more sensitive isotopic methods. While this manuscript was in preparation, a brief abstract by Anderson \& Jones (1959) appeared in which they claimed to have demonstrated carbamyl phosphate-synthetase activity in Squalis sp. Our failure to detect the enzyme in $S$. sucklii was surprising, for carbamyl phosphate-synthetase activity has always been observed in the liver of adult animals whenever activity for ornithine transcarbamylase could be demonstrated (see below).

Ornithine transcarbamylase was easily demonstrable in liver preparations from S. sucklii. The production of citrulline by a water extract of a potassium chloride-prepared pellet is shown in Fig. 3. This observation confirms the findings of Brown (1959) and of Baldwin (1958) on the occurrence of this enzyme in elasmobranch liver and demonstrates further the substrate requirements, the heat inactivation of the enzyme and the occurrence of the enzyme in the $4000 \mathrm{~g}$ fraction. The activity of the enzyme as a function of $\mathrm{pH}$ in $0.045 \mathrm{M}$-glycylglycine buffer is shown in Fig. 4 . The optimum $\mathrm{pH}$ of 8.2 and the general shape of the curve corresponds to that observed by Burnett \& Cohen (1957) with partially purified ox-liver ornithine transcarbamylase.

Carbamyl phosphate-synthetase activity in relation to amphibian development. Necturus is a neotenic, perennibranchiate salamander that has carried over certain larval characteristics (e.g. external gills) to the adult stage. Of the various ureotelic animal livers assayed, that of Necturus possessed the lowest levels of carbamyl phosphate synthetase as well as of ornithine transcarbamylase and of the 
arginine-synthetase system. The highest level of carbamyl phosphate synthetase observed with Necturus was 22 units/g., which is below the average value of $360 \pm 80$ units/g. observed with seven salamanders of the genus Ambystoma. The low value observed with Necturus liver is reminiscent of the values for carbamyl phosphate synthetase found with incompletely metamorphosed frog tadpoles of Rana catesbeiana (Brown \& Cohen, 1958, 1959b). Thus the level of this enzyme again shows a correlation with the degree of metamorphosis which an amphibian undergoes.

Amphiuma means is an eel-shaped, largely aquatic amphibian which possesses miniature paired limbs. The adult Amphiuma is a form which is at a later stage of urodele ontogeny than is Necturus (Noble, 1931). Two specimens of $\mathrm{Am}$ phiuma showed activity of 175 and 238 units/g. for carbamyl phosphate synthetase, somewhat higher than for Necturus and about equal to that of Ambystoma, but considerably less than that for the Anura. Frogs and toads, which have attained a greater degree of development than other am. phibians, exhibited activities from about 700 to 1000 units/g. The last-named values are of the order of those observed in rat liver.

The level of carbamyl phosphate synthetase can be correlated with the extent of amphibian development. Thus the level of this enzyme increases with the extent of development in this order: Necturus, Amphiuma, Ambystoma, Rana $\cong$ Bufo.

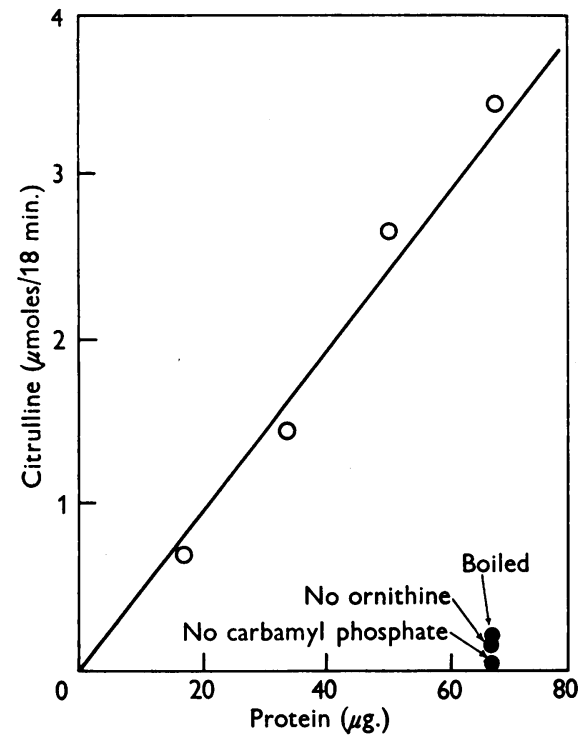

Fig. 3. Ornithine transcarbamylase from liver of Squalis sucklii Bernard. Rate of production of citrulline and protein concentration.
Arginase activity of the liver of saurian reptiles. Extracts prepared from the liver of the western alligator lizard, Gerrhonotus multicarinatus multicarinatus Blainville, showed a low but significant amount of arginase activity. The results of a typical experiment with this animal are given in Table 2.

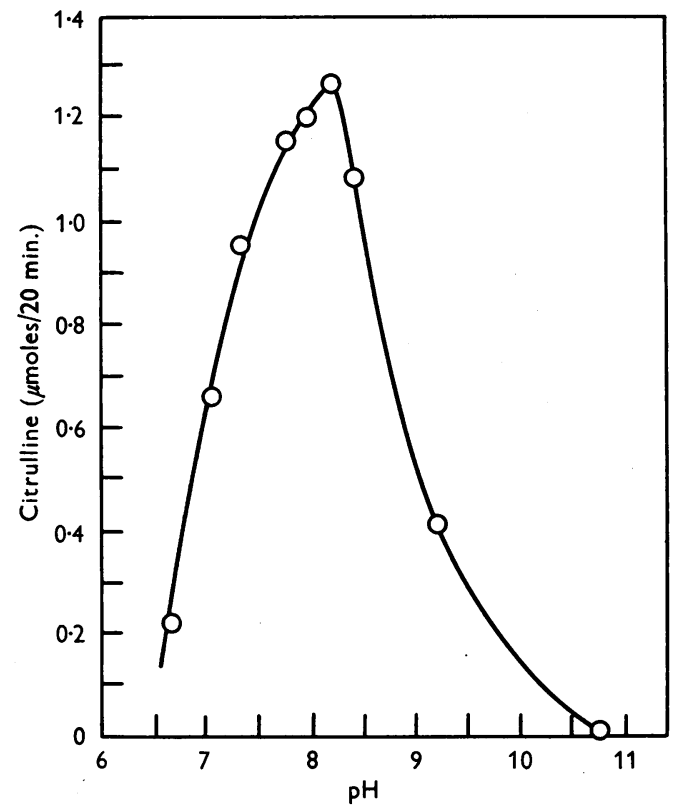

Fig. 4. Optimum $\mathrm{pH}$ for ornithine transcarbamylase of Squalis acanthius. The system contained: $33 \mu \mathrm{g}$. of protein: water extract of KCl-prepared pellet; $1 \mathrm{ml}$. incubation volume (modification); glycylglycine buffer, $0.045 \mathrm{M}$.

Table 2. Arginase activity of the liver of the lizard Gerrhonotus multicarinatus multicarinatus Blainville

A $10 \%$ water homogenate $(0.4 \mathrm{ml}$. containing $8.8 \mathrm{mg}$. of protein $/ \mathrm{ml}$.) was incubated for $1 \mathrm{hr}$. at $38^{\circ}$ in the presence

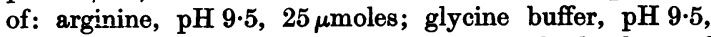
$50 \mu$ moles; $\mathrm{MnCl}_{2}, 0.5 \mu$ mole; water to give a final volume of $2 \mathrm{ml}$. (complete system). When solutions of components of the reaction mixture were omitted, an equivalent volume of water was added to bring the final volume to $2 \mathrm{ml}$. Tubes with urease contained $1 \mathrm{mg}$. of partially purified urease. Reactions were stopped with $5 \mathrm{ml}$. of $0.5 \mathrm{M}$-perchloric acid and the clear supernatant solution after centrifuging was analysed for urea with 1-phenyl-1:2-propanedione-2-oxime. Figures given are for duplicate assays.

\begin{tabular}{lc}
\multicolumn{1}{c}{ System } & $(\mu$ moles $/ \mathrm{hr})$. \\
Complete & $2 \cdot 17,2 \cdot 02$ \\
Mn $^{2+}$ ions omitted & $1 \cdot 12, \mathbf{1} \cdot 13$ \\
Arginine omitted & $0 \cdot 02,0 \cdot 01$ \\
Complete but with boiled extract & $0 \cdot 04,0 \cdot 04$ \\
Urease added & 0,0
\end{tabular}

Urea produced $1 \cdot 12,1 \cdot 13$ $0.04,0.04$ 
A value of $18.9 \pm 0.7$ units/g. was observed for the liver of this specimen. Omission of the substrate, arginine, from the assay system, boiling of the extract or carrying out the incubation in the presence of urease (to destroy any urea produced) led to a negligible amount of product. A partial dependence upon manganese was also demonstrated. In a similar type of experiment, arginase activity was demonstrated for garter-snake liver, two specimens yielding 56 and 99 units/g. Several species of lizards have now been shown also to possess liver-arginase activity (G. W. Brown \& P. P. Cohen, unpublished work). Heretofore such activity was thought to be absent from these vertebrates (Clementi, 1915).

$\mathrm{N}$-Acetyl-L-glutamate as cofactor for carbamyl phosphate synthetase. Vertebrate carbamyl phosphate synthetase requires as a cofactor a lowmolecular-weight acyl derivative of L-glutamate (Grisolia \& Cohen, 1953). The following (in $\mu$ moles/ ml.) would not replace $N$-acetyl-L-glutamate with frog carbamyl phosphate synthetase : acetylglycine, 20 ; folic acid, $5 ; p$-aminobenzoyl-L-glutamate, 5 ; glycylglycine, 5; acetamide, 2 . The following did not compete with $N$-acetyl-L-glutamate at comparable levels: acetylglycine; $p$-aminobenzoyl-Lglutamate; acetamide. The persistence of the requirement for $N$-acetyl-L-glutamate among the ureotelic vertebrates suggests that carbamyl phosphate synthetase underwent little, if any, structural modification at the active site on the enzyme protein throughout the course of vertebrate evolution.

Nitrogen excretion. In several cases the nitrogen partition of the bladder fluid of certain animals was determined. One specimen of Bufo fowlerei showed $24 \mu \mathrm{moles}$ of $u \mathrm{rea} / \mathrm{ml}$. of fluid, corresponding to $98 \%$ of the ammonia nitrogen plus urea nitrogen. Bladder fluid of two specimens of Bufo marinus contained 92.5 and $89.4 \%$ of the total excretory nitrogen (ammonia + urea) as urea nitrogen. The percentage of urea nitrogen in several specimens of Ambystoma tigrinum was between 87 and 97. One bladder-fluid sample from an Amphiuma contained 3.2 and $14.4 \mu$ moles of ammonia and urea respectively $/ \mathrm{ml}$. of fluid, corresponding to $90 \%$ of excretory nitrogen as urea nitrogen. To our knowledge this is the first report on this nitrogen partition in the urine of this species. The observed nitrogen partitions confirm the view that these amphibians are ureotelic in the adult form.

\section{Evolutionary significance of the findings}

The acquisition of new enzymes by mutation is considered to play a significant role in the evolution of new species. But the deletion of enzymes (Potter, 1957) must also be considered as contributing to the route for the origin of new species.
Both types of enzymic alterations, when otherwise not lethal, tend to increase the likelihood that such altered forms will extend their ecological niche (or assume a new one). The thesis is advanced that both types of enzymic alterations, i.e. acquisition and deletion, when related to a given function work in concert in serving the overall economy of the organism. For example, we can consider that the deletion of the urea-cycle enzymes but with acquisition, retention and/or augmentation of those enzymes involved in uric acid synthesis permitted a greater freedom from an aqueous, external environment in embryonic life (Needham, 1942). The possession of a system for the synthesis of uric acid may be looked upon as an enzymic preadaptation, which can be brought into play if and when loss of urea synthesis subsequently occurs. This presumably occurred during evolution of the reptiles. On the other hand, loss of a functioning urea-synthesizing system in certain primitive fishes without concomitant enhancement of net uric acid synthesis appears to be responsible for the excretion by the Teleostei of much of their waste nitrogen as ammonia. Teleosts have made inroads, however, on another form of nitrogen excretion, notably that of trimethylamine oxide (Grollman, 1929).

Although it is not possible at present to consider all of the possibilities of deletion and acquisition of urea-cycle enzymes throughout the sequence of

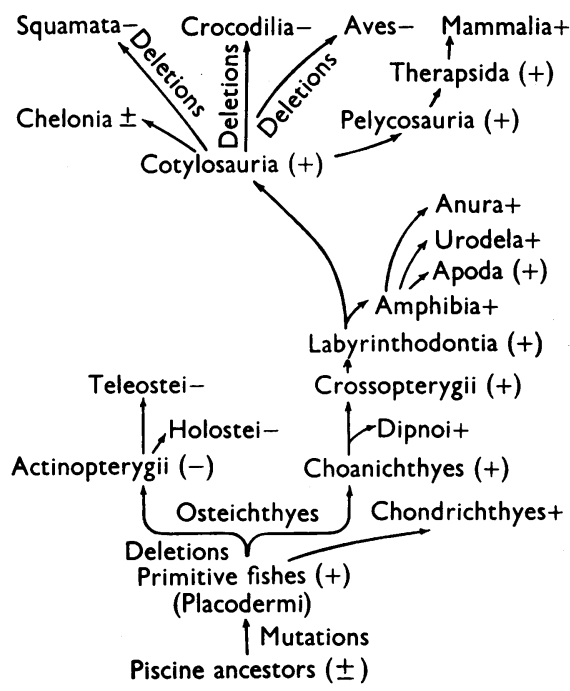

Fig. 5. Evolutionary tree of vertebrates. (+), Postulated presence and (-), postulated absence, of functioning urea cycle. Signs without parentheses indicate that the group possesses members known to possess or to lack the functioning complement of urea-cycle enzymes. 'Deletion' indicates site of postulated loss of activity of one or more enzymes of the urea cycle. 
evolution of the vertebrates, certain assumptions can be made which offer a tentative explanation for the distribution of urea-cycle enzymes in the livers of extant vertebrates. It seems advisable to restate the sequence of evolution of nitrogen-excretion mechanisms in the light of the present findings and those presented elsewhere (Needham, 1931; Baldwin, 1949).

The evolutionary tree, as modified from several sources (Noble, 1931; Romer, 1945, 1956), from piscine ancestors to the higher vertebrates, is shown in Fig. 5. The picture which emerges is this: at some time there arose primitive fishes, possibly the Placodermi, possessing probably the complement of urea-cycle enzymes; these primitive fishes were derived from ancestors which possessed enzymes of the urea cycle. As depicted elsewhere (Brown \& Cohen, 1958; Ratner, 1955), the urea cycle can operate as such in the intact animal presumably only with the co-operation of four ancillary reactions providing a source of aspartate for the synthesis of argininosuccinate. Thus at least nine enzymes, and presumably at least nine genetic loci, were required before the urea cycle could function as a mechanism for the disposal of ammonia as urea; it seems illogical to assume that these enzymes arose in one evolutionary step, but rather that the evolution of the cycle occurred in stages.

That enzymes of the urea cycle were being exploited in Nature before the evolution of the cycle as a mechanism for the excretion of nitrogen is shown by the widespread occurrence of such enzymes in a variety of plant, animal and bacterial sources (see Brown \& Cohen, 1958; Ratner, 1954, 1955). It appears likely that the final acquisition of the complement of urea-cycle enzymes was a process involving a series of mutations serving the economy of primitive and diverse forms in various ways. Thus the enzymes preceding arginase in the cycle offer a route for the synthesis of arginine for protein synthesis and for synthesis of creatine and arginine phosphate.

The assignment of an active urea cycle with its complement of enzymes to certain primitive fishes is based upon the ureotelism exhibited by sharks (of Chondrichthyes), which derived at about the same time from the same general stock as did the Actinopterygii (ray-finned fishes) and the Choanichthyes (possessing internal nostrils associated with lung breathing). It is suggested that certain deletions of enzymes of the urea cycle occurred in the evolvement of the Actinopterygii, for the modern Holostei and Teleostei do not possess all of the enzymes of the urea cycle and are ammonotelic. The term deletion is to be interpreted to mean the lowering of enzymic activity to such a level that the urea cycle no longer functions to any significant extent as a system for the disposal of ammonia as urea. In the instances cited, it is not known whether or not the absence of activity can be attributed to the loss of primary genetic information for the synthesis of - individual enzymes. Choanichthyes, the other major subclass of Osteichthyes, is assigned all of the urea-cycle enzymes, as are the later Crossopterygii (Middle Devonian bony fishes) and Labyrinthodontia (primitive amphibians), since higher branches of this stem, e.g. the dipnoans (lungfishes) and amphibians, are ureotelic.

The Cotylosauria ('stem reptiles') are also assigned an active urea cycle since an early branch, the Chelonia, possesses members containing the urea-cycle enzymes, e.g. Chrysemys (cf. Moyle, 1949, for ureotelic species). The reptilian Pelycosauria and Therapsida, antecedent to Mammalia, are derived from the main stem stock of reptiles and would be thought still to possess the urea-cycle enzymes. Deletions within the stem reptiles are presumed to have occurred, for Aves, Crocodilia and Squamata do not excrete appreciable amounts of urea, nor are they known to possess the complement of urea-cycle enzymes. The assignment of urea-cycle activity in extinct forms can, of course, come only from indirect evidence. Knowledge on the occurrence or absence of urea-cycle enzymes in the livers of species occupying peculiar phylogenetic positions such as the platypus, coelacanths and the New Zealand sphenodon, could provide valuable information.

Emphasis on net uric acid synthesis is presumed to have occurred sometime during early reptilian development, for chelonian reptiles have the ability to excrete their nitrogen as ammonia, urea and/or uric acid, depending upon species (Moyle, 1949; Khalil \& Haggag, 1955) and possibly on environment (Clementi, 1952).

Arginase shows marked persistence throughout the course of vertebrate evolution, for birds (uricotelic) contain arginase in the kidney (Clementi, 1915), although at a lower activity than is found in the livers of amphibians or mammals. This enzyme is also found in the livers of the Teleostei to varying degrees (Hunter \& Dauphinee, 1924). For 45 years arginase has been thought to be absent from squamatine liver (Clementi, 1915). Our observations on the occurrence of arginase in the liver of the western alligator lizard and the garter snake (see above) as well as in several other species of lizards (unpublished work) are, we believe, the first observed exceptions to the rule of Clementi that arginase is absent from the liver of such uricotelic vertebrates. The activities of liver arginase in descending order in the vertebrates appear to be sharks $\cong$ frogs, turtles, lizards $\cong$ snakes, birds (absent entirely?). That the level of liver arginase tends to decrease in this order supports the view 
that there has been a progressive loss in liverarginase activity during the course of sauropsidian evolution.

Alternative hypotheses can certainly be offered to explain the enzymic alterations of the urea-cycle enzymes in the evolutionary tree. For example, there could have been deletions and back-mutations (to regain the enzymes) of certain enzymes of the urea cycle almost anywhere in the scheme. Whereas such changes indeed may have occurred, the suggestion at present of such changes seems unwarranted; only a simple and tentative hypothesis consistent with our present state of knowledge has been made.

Smith (1953) has already suggested that urea was the principal nitrogenous end product of protein degradation in Therapsida and Crossopterygii. Smith's conclusions were based, among other things, on renal structure, function and osmotic balances as derived from the contributions of palaeontology and comparative anatomy. Our independent conclusion is based upon the presence of urea-cycle-enzyme activities in elasmobranchs, amphibians, certain chelonian reptiles and mammals, and the phylogenetic relationship to these of the therapsids and the crossopterygians. Contrary to Smith, however, we do not classify teleosts as ureotelic because (i) only small quantities of urea are excreted by teleosts, compared with ammonia, creatinine, trimethylamine and other unidentified nitrogenous products, depending upon species (cf. Prosser, 1950), and (ii) all experimental evidence for the occurrence of the ornithine-urea cycle in teleosts is negative.

Comments pertaining to acquisition and deletion of enzymes in relation to the occurrence or absence of enzymes in extant vertebrates is not to be confused with the phenomenon of the induction of the urea cycle in tadpoles which takes place during metamorphosis (Brown \& Cohen, 1958, 1959b). The genetic pattern for synthesis of urea-cycle enzymes is present in premetamorphic tadpoles but is not manifested in its entirety until the onset of metamorphosis. It may be thought that the genetic pattern for all urea-cycle enzymes is present in the bird egg but that deletion during ontogeny results in the loss of all of the urea-cycle enzymes (except arginase) sometime before hatching. Such an idea of recapitulation was popular for a while and was based on a graph of nitrogen-excretion products in the developing chick embryo published by Needham (1931). This graph has appeared in at least five other books (Baldwin, 1949, 1957; Florkin, 1947; Moody, 1953; Prosser, 1950). But Needham, Brachet \& Brown (1935) long ago concluded, and more recently it has been shown (Eakin \& Fisher, 1958; Ricceri, 1957), that during embryonic development the bird does not go through an evolutionary recapitulation from ammonia to urea to uric acid excretion, with the resulting temporary acquisition of urea-cycle enzymes. The formation of urea in chick embryos finds explanation in the action of arginase on arginine derived from yolk proteins. Gordon (1956) revived this idea of recapitulation and offered evidence for the occurrence of carbamyl phosphate synthetase and ornithine transcarbamylase in 9-day-old chick embryos. An attempt to repeat this experiment in the authors' Laboratory was unsuccessful.

In view of the fact that a low but significant level of arginase activity has now been observed in lizard and snake liver, where previously it was thought to be absent, and because of conflicting reports of arginase activity in adult avian liver (Chaudhuri, 1927; Clementi, 1946), the status of the occurrence of liver arginase needs to be evaluated again. It is unlikely that such a study would change the general conclusions about the phylogenetic distribution of nitrogen excretion patterns. Studies of this kind, however, might provide information about the nature and extent, and possibly the evolutionary loci, of enzymic alterations which have yielded the excretion patterns in extant species.

\section{SUMMARY}

1. Activities of urea-cycle enzymes in the livers of a variety of lower and higher vertebrates are presented. All amphibians and mammals studied possessed the urea-cycle enzymes, as did the painted turtle (terrapin), Chrysemys picta.

2. The activity of carbamyl phosphate synthetase reflects the extent of amphibian development, showing an increase in activity with greater development.

3. A scheme is presented of the phylogenetic relationships of extinct and extant vertebrate groups with indication of stages in the evolutionary sequence where deletions of urea-cycle enzymes could have occurred.

4. Data are presented on the occurrence of ornithine transcarbamylase in shark liver.

5. Of all the animals investigated, bats possessed the highest levels of carbamyl phosphate synthetase.

6. An exception to the rule of Clementi, namely that arginase is absent from the livers of uricotelic animals, has been found. Arginase activity was demonstrated in lizard and snake liver.

We are indebted to Dr William G. Reeder of the Department of Zoology for his valuable comments and suggestions on our phylogenetic chart and to Dr W. Welker of the Department of Physiology, who supplied us with kinkajou, opossum, bat and rattlesnake livers. We wish to thank Drs A. W. Martin and D. D. Chapman of the Department of 
Zoology, University of Washington, Seattle, for extending to one of us (G.W.B.) facilities for carrying out studies with shark liver at the Oceanographic Laboratory in Seattle and at the Marine Biological Station at Friday Harbor in August 1958. Appreciation is also expressed to Dr John C. Neess of the Department of Zoology for classifying several of the specimens for us.

This study was supported in part by grants from the National Science Foundation, the National Institutes of Health and the Wisconsin Alumni Research Foundation.

\section{REFERENCES}

Anderson, A. D. \& Jones, M. E. (1959). Abstr. 135th Meet. Amer. chem. Soc.: Div. biol. Chem. no. 126.

Baldwin, E. (1949). An Introduction to Comparative Biochemistry, 3rd ed. Cambridge University Press.

Baldwin, E. (1957). Dynamic Aspects of Biochemistry. Cambridge University Press.

Baldwin, E. (1958). Nature, Lond., 181, 1591.

Brown, G. W., jun. \& Cohen, P. P. (1958). In A Symposium on the Chemical Basis of Development, p. 495. Ed. by McElroy, W. D. \& Glass, B. Baltimore: The Johns Hopkins Press.

Brown, G. W., jun. \& Cohen, P. P. (1959a). J. biol. Chem. 234, 1769.

Brown, G. W., jun. \& Cohen, P. P. (1959b). J. biol. Chem. 234, 1775.

Brown, W. D. (1959). M.D. Thesis: University of Wisconsin Medical School.

Burnett, G. H. \& Cohen, P. P. (1957). J. biol. Chem. 229, 337.

Chaudhuri, A. C. (1927). Brit. J. exp. Biol. 5, 97.

Clementi, A. (1915). Arch. Fisiol. 13, 189.

Clementi, A. (1946). Boll. Soc. ital. Biol. sper. 22, 1075.

Clementi, A. (1952). Arch. Sci. biol., Napoli, 36, 10.

Cohen, P. P. \& Brown, G. W., jun. (1959). In Comparative Biochemistry, Ed. by Florkin M. \& Mason, H. S. New York: Academic Press Inc. (in the Press).

Eakin, R. E. \& Fisher, J. E. (1958). In A Symposium on the Chemical Basis of Development, p. 514. Ed. by McElroy, W. D. \& Glass, B. Baltimore: The Johns Hopkins Press.
Florkin, M. (1947). L'Évolution Biochimique, 2nd ed. Paris and Liège: Masson et Cie and Desoer.

Gordon, M. W. (1956). In Progress in Neurobiology. Vol. 1 : Neurochemistry. Ed. by Korey, S. R. New York: P. B. Hoeber.

Grisolia, S. \& Cohen, P. P. (1953). J. biol. Chem. 204, 753.

Grollman, A. (1929). J. biol. Chem. 81, 267.

Hunter, A. \& Dauphinee, J. A. (1924). Proc. Roy. Soc. B, 97, 227.

Khalil, F. \& Haggag, G. (1955). J. exp. Zool. 130, 423.

Kim, S. (1959). Ph.D. Thesis: University of Wisconsin Medical School.

Krebs, H. A. \& Henseleit, K. (1932). Hoppe-Seyl. Z. 210, 33.

Moody, P. A. (1953). Introduction to Evolution. New York: Harper and Bros.

Moyle, V. (1949). Biochem. J. 44, 581.

Needham, J. (1931). Chemical Embryology, vol. 2. Cam. bridge University Press.

Needham, J. (1942). Biochemistry and Morphogenesis. Cambridge University Press.

Needham, J., Brachet, J. \& Brown, R. K. (1935). J. exp. Biol. 12, 321.

Noble, G. K. (1931). The Biology of the Amphibia. New York: McGraw-Hill Book Co. Inc.

Potter, V. R. (1957). Med. Bull. Univ. Mich. 23, 401.

Prosser, C. L. (1950). In Comparative Animal Physiology, p. 187. Ed. by Prosser, C. L. Philadelphia: W. B. Saunders Co.

Ratner, S. (1954). Advanc. Enzymol. 15, 319.

Ratner, S. (1955). In A Symposium on Amino Acid Metabolism, p. 231. Ed. by McElroy, W. D. \& Glass, H. B. Baltimore: The Johns Hopkins Press.

Ricceri, G. (1957). Ital. J. Biochem. 6, 353.

Romer, A. S. (1945). Vertebrate Paleontology. Chicago: University Press.

Romer, A. S. (1956). A Shorter Version of the Second Edition of the Vertebrate Body. Philadelphia: W. B. Saunders Co.

Smith, H. W. (1953). From Fish to Philosopher. Boston: Little, Brown and Co.

\title{
Studies on the Chemical Basis of the Antigenicity of Proteins
}

\section{ANTIGENICITY OF POLYPEPTIDYL GELATINS}

\author{
By M. SELA AND RUTH ARNON \\ Department of Biophysics, The Weizmann Institute of Science, Rehovoth, Israel
}

(Received 23 July 1959)

Most proteins have been tested for antigenicity, and practically all have been found to be antigenic, though to a varying extent. Although antigens of non-protein nature are also known, the proteins seem to be the most abundant and important antigenic substances yet studied. It is the purpose of this series of investigations to try to establish some correlation between the chemical nature of the protein antigens and their immunological activity.

To be antigenic, a molecule must possess a certain minimal degree of complexity and a certain mole- 